\title{
Understanding of Mitosis and Meiosis in Higher Secondary Students of Northeast India and the Implications for Genetics Education
}

\author{
Ansuman Chattopadhyay \\ Department of Zoology, Visva-Bhatati, 731235, Santiniketan
}

\begin{abstract}
Cell division, perhaps the most important is among the most difficult topics in biology to teach. With respect to the observation of the previous study on understanding of 'genetic information' in higher secondary (junior college level) students, the present study was carried out to examine the same students' understanding of mitosis and meiosis. A total of 289 students from three undergraduate colleges were given written questionnaire having both fixed and free answer-type questions. It was found that students had a wide range of misconceptions in the process of cell division. The types of alternative concepts were identified in this study. The study revealed that a significant number of students did not understand the primary differences between the two cell division processes, the importance of the maintenance of chromosome numbers in mitosis, the significance of the formation of germ cells with haploid number of chromosomes and the recombination events taking place during meiosis and their implications. This results corroborates the earlier study among middle school children, conducted by the "Learning in Science Research Group" of Leeds University in UK. The probable reasons for the confusions surfaced in this study and the possible approaches to overcome the difficulties in classroom teaching of cell division processes, particularly in countries like India are discussed in this paper.
\end{abstract}

Keywords Cell Division, Mitosis; Meiosis, Higher Secondary Students, Northeast India, Genetics Education

\section{Introduction}

The last half of the 20th century saw rapid strides in the science of genetics beginning with the discovery of the structure of DNA molecule, introduction of the recombinant DNA technology and culminating with the completion of Human Genome Project (HGP). All these gave rise to new disciplines/areas of work in biology for which a good foundation of genetics particularly at school level is extremely essential. Concept in genetics is closely linked with knowledge and understanding of topics like cells, cell division fertilization etc. Previous studies at different levels in various countries reported a poor understanding of these topics among students[1-3]. Similar study in India is rarely reported. In an earlier study, I have examined the understanding of genetic information in cells within an individual and its transmission during fertilization for higher secondary (junior college level) students of northeast India[4]. The study showed that a significant proportion of students were confused about the type of similarity/difference of genetic information in cells of different tissues in an individual,

* Corresponding author:

ansumanchat@yahoo.com (Ansuman Chattopadhyay)

Published online at http://journal.sapub.org/edu

Copyright (C) 2012 Scientific \& Academic Publishing. All Rights Reserved particularly in sex cells. They could not recognize that sex cells of the same individual carry different genetic information resulting by recombination of genetic material through crossing over as well as random distribution of parental chromosomes during segregation in meiosis I. Since such responses might be associated with their knowledge and understanding of cell division, a further study was conducted with the same students to examine their understanding about mitosis and meiosis by analysing the explanation of the students in support to their choices for fixed-answer type questions. In this paper, it is also discussed what alternative strategies could be adopted at school level to overcome the shortcomings in teaching cell division, which is often considered as one of the most difficult topics to be taught in biology[5], particularly in countries like India, where the infrastructural facilities in majority of the public schools are meagre.

\section{Theoretical Framework}

Genetics is basically an abstract and conceptual subject. Misconceptions, part of a student's line of reasoning, developing at the early stage of school level, if not addressed at right time, keep on hovering in the students conceptual frame work even in later part of their career[6]. Sound understanding of a concept requires an accommodation following 
a state of disequilibrium. If the student experiences are skillfully guided at this stage, the misconceptions which may develop by unchecked accommodation may be avoided or disentangled[6,7]. Therefore the study of misconceptions could be of great help in instruction, particularly in genetics education.

\section{Indian Educational System}

The present educational system in India includes school, college and university levels. The school system extends from kindergarten to class XII, which has four categories, primary (I-V), middle (VI-VIII), secondary (IX-X) and junior college or higher secondary (XI-XII) levels[8]. Though the higher secondary (class XI and XII) level is considered as a part of school education, it is taught mostly in undergraduate colleges. Efforts are on to open these classes (XI and XII) in schools by upgrading them from secondary to higher secondary standards and providing necessary man power and infrastructural facilities.

An autonomous Central Government organization named, 'National Council for Educational Research and Training (NCERT)', prepares the broad guide lines of the school syllabus up to higher secondary level. It also publishes text books, which are followed by Central Schools, funded by Central Government particularly for the children of the Central Government employees with transferable jobs located at different parts of the country. The State governments have their own State Education Departments with government aided schools, which follow the broad pattern of syllabus laid down by NCERT. Government affiliated private schools also operate in many states which follow either the syllabus of NCERT or the State Educational Boards.

\section{Portions of Cell Biology and Genetics Syllabus Taught at Higher Secondary Level in Meghalaya Board of School Education Related with the Present Test}

\section{Cell as basic unit of life}

Discovery of cell, cell theory, cell as a self-contained unit; prokaryotic and eukaryotic cells; unicellular and multicellular organisms; Ultrastructure of prokaryotic and eukaryotic cell - cell wall, cell membrane - unit membrane concept (the fluid mosaic model); membrane transport; Cell organelles and their functions - nucleus, mitochondria, plastids, endoplasmic reticulum, Golgi complex, lysosomes, microtubules, centriole, vacuole, cytoskeleton, cilia and flagella, ribosomes.

Molecules of cells including nucleotides, nucleic acids (DNA and RNA). Cell cycle: significance of cell division, amitosis, mitosis and meiosis; karyotype analysis.

The topics, structure \& function of 'cells' and 'cell divi- sion' are also taught at the secondary level ( class IX and X) in science curriculum.

\section{Genetics}

Continuity of life - heredity, variation; Mendel's laws of inheritance-incomplete dominance, multiple allelism, quantitative inheritance.

Chromosomes - bacterial cell and eukaryotic cell; parallelism between genes and chromosomes; genome; linkage and crossing over; gene mapping; recombination; sex chromosomes; sex determination; sex linked inheritance; mutational and chromosomal aberrations; Human genetics-methods of study, genetic disorders.

DNA as a genetic material-its structure and replication; structure of RNA and its role in protein synthesis; Gene expression, transcription and translation in prokaryotes and eukaryotes (regulation of gene expression, induction and repression, housekeeping genes; nuclear basis of differentiation and development); oncogenes.

Basics of recombinant DNA technology; cloning; gene bank; DNA fingerprinting; genomics-principles and applications, transgenic plants, animals and microbes.

\section{Methodology}

\subsection{Questionnaire Used}

A written questionnaire, developed by Lewis et al.[1] as part of the "Learning in Science Research Group", Leeds University was used with permission. It combines both fixed- and free-answer type questions. Even though the questionnaire was used in United Kingdom for middle school children, the same was used in this study for higher secondary students. The justification of using the questionnaire was that it was prepared by a well-experienced group, working in genetics education and it was already tested among students[1-3,9]. In addition, this questionnaire was designed to assess conceptual understanding of topics also included in Indian curriculum. The same responses to the multiple choice questions which were considered to be correct in the previous study[1] were taken as correct responses (to the multiple choice questions) in this study.

\subsection{Sample of Students}

The study was conducted with a sample size of 289 students (158 boys and 131 girls) of class XII (16-18 years old) from three different undergraduate colleges in Shillong, Meghalaya, a state in northeast India. Among these colleges, one was for boys only, one college was for girls only and the third was coeducational. The same syllabus, laid down by the State Educational Board was followed in all these colleges. The students had the same science backgrounds and compled 2 -yr higher secondary courses. They would have been expected to know the answers to the questions asked in the questionnaire used.

\subsection{Administration of Questionnaire to the Students}

The questionnaire was administered at each of the re- 
spective college classes within a class period of $45 \mathrm{~min}$ with the help of the class teachers. Questionnaire was distributed to all the students present in the classes. Care was taken to avoid any exchange of information or ideas among students.

\section{Results}

The 'Cell division' section is in two parts:

Part 1 included questions asking about cell division for growth and repair (focused on Mitosis).

Part 2 included questions asking about cell division for the production of sex cells (focused on Meiosis).

Students' responses to each question are given in Table 1 and Table 2. Because students' explanations cannot be aggregated for the entire section, explanations of responses to each question are reported below.

\section{Part 1. Questions related to Mitosis:}

In animals, skin cells divide again and again to produce many new skin cells.

Figure showing diagram of a cell with four chromosomes, mentioned as 'Original Skin Cell'.

Question 1. If the original skin cells contained the chromosomes shown in the diagram above, what chromosomes do you think the new skin cells would contain?

Look at the diagram below and tick ONE to show which chromosomes you think would be found in the NEW SKIN CELLS. Please give reasons for your answer. (The choices were 8, 4, 2 number of chromosomes and don't know).

As noted in Table $1,44.5 \%$ of the students thought, the new cells should have 8 chromosomes. The various explanations given by the students were as follows:

"Because chromosomes will divide more and more,"

"The original skin cell divides again and again to produce many new skin cells,"

"Since it divides twice the original number,"

"In mitosis the cell will produce ' $2 \mathrm{n}$ ' number of chromosomes,"

"Each chromosome divides to give rise to two new chromosomes. Hence 4 chromosomes in original cell will multiply to give 8 in new one,"

"According to the process of cell division we know that one cell divides to form two separate cells. Therefore here also we find that four different chromosomes will give eight separate/individual chromosomes,"

"Since the skin cell continues to divide, it increases in number,"

"Because these cells divide many new cells which are more in number than the original one," or

"Because they produce twice the original numbers so two chromosomes are produced."

Among others, $38.5 \%$ correctly said that the number would remain 4 . Of these, $41 \%$ of students who gave correct answer properly explained that skin cells undergo mitosis and the number of chromosomes remains same after such cell division, e.g. "The chromosomes first multiply and then divide to give new cell with same number of chromosomes" and "Mitotic cell division maintains chromosome number."

The scientifically incorrect explanations by the students were as follows:

"The same cells because they are divided in structure, not in function,"

"Because skin cells divide to produce many new skin cells not to produce more chromosomes," or

"Because it is the process of meiosis."

Fourteen per cent thought that there should be only 2 chromosomes after the division giving as rationale that:

"The chromosome number reduces to half," or

"The chromosome in the new cell will be half of the original one."

Four per cent of the students did not know the answer.

Question 2. Would the new skin cells and the original skin cell contain the same or different genetic information?

Please tick ONE, and then give your reasons.

Majority of the students $(76.5 \%)$ correctly said that the genetic information would remain same in the mother cell and newly divided daughter cells though only $47 \%$ of them had a valid reason to support their response.

The various explanations by the students included as follows:

"Because they are from the same cell and are of the same type,"

"Because they are inherited from same genes,"

"Since both these two give information to the brain,"

"Because they come from the same species,"

"Because the chromosomes divided from the parent cell,"

"The same genes would be transferred to the new skin cell,"

"Genes are being transferred from one cell to new cells,"

"Since they have the same origin and they are haploid condition ( $\mathrm{n}=$ number of chromosome),"

"The daughter cell will contain the same number of chromosomes as the mother cell,"

"Because the new cell is the modification of original cell,"

"They will carry the same genetic information since in this type of cell division there is no transfer of genes between two chromosomes,"

"Because the new skin cell is obviously going to have all the genetic information of the original skin cell,"

"Because they belong to the same organism with same structural and functional units," or

"Because they developed from the same cell, so they will perform same job."

Another $20 \%$ thought that the information would be different, e.g. "Since in original skin cell some of the cells have died" and "Because an animal skin shrinks due to aging." Five percent of the students did not know the answer.

Question 3. For each part of the body listed below please tick ONE to show whether or not you think the cells in that part of the body would divide in this way.

$\begin{array}{lll}\text { muscle } & \text { yes } & \text { no } \\ \text { testis } & \text { yes } & \text { no }\end{array}$




$\begin{array}{lll}\text { ovary } & \text { yes } & \text { no } \\ \text { kidney } & \text { yes } & \text { no } \\ \text { stomach } & \text { yes } & \text { no }\end{array}$

For this question, reason was not asked.

Majority of the students (81\% for muscle, $62.5 \%$ for kidney and $58.5 \%$ for stomach) said 'yes' to these somatic tissues though $39 \%$ and $51.5 \%$ of the students, respectively, thought that testis and ovary undergo mitotic division.

Question 4. The questions so far have all been about animal cells.

Do you think that this type of cell division for growth also occurs, in the same way, in plants?

Please tick ONE, and then give your reasons.

Yes no

Sixty per cent of the students said 'yes' to this response though only $29 \%$ had a valid reason for their answer mostly on the line that plants also need to grow for which they undergo mitotic division, e.g.

"Because even plants grow like animals,"

"Because they both are living organisms," or

"The type of cell division in plants and animals are almost equal as both are living creatures."

The invalid reasons include "Because plants respire through cell division through xylem and phloem performs their work."Students who thought that plants do not have similar type of cell division to animals gave reasons like: "Because the contents of plants and animal cells are not same," "Since the plants bear cell which are different from animal cell i.e. in case of cell wall which is present only in plants and not in animals," "Because most of the plants are different in their structure and function," "Since the monocotyledons lost the secondary growth due to absence of cambium," or "Plants and animals have different structure and physiology."

Table 1. Students' responses about mitosis

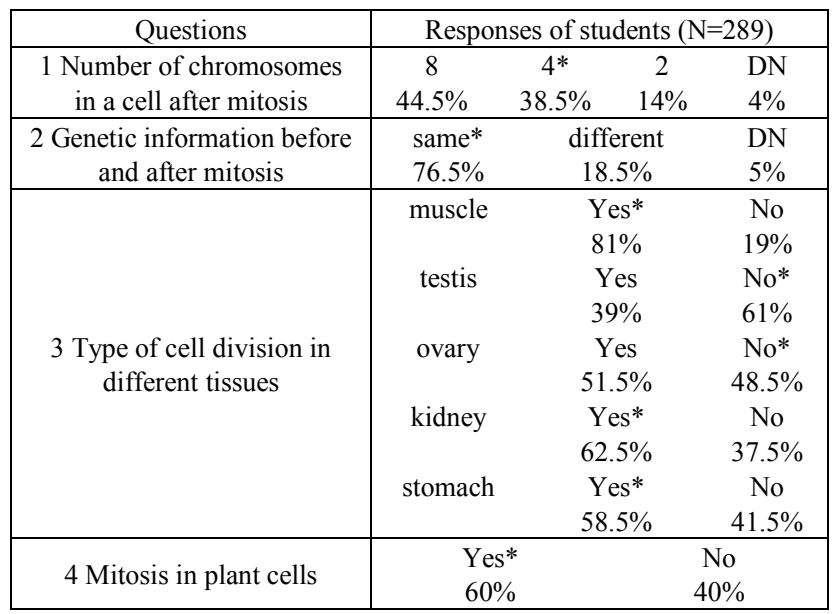

It should be noted that cytokinesis does occur differently during mitosis in plants and animals and therefore in strict sense these two types of cell division are different, this was not mentioned by any student as a rationale to their choice of response as 'different'.

\section{Part 2. Questions related to Meiosis:}

Question 1. Cells also divide when sex cells (eggs and sperm) are being produced.

a) If the original cell contained the chromosomes shown in the diagram above (4 in number), what chromosomes do you think the egg cell would contain?

Please give reasons for your answer.

The choices are: Twice the original number; the original number; half the original number; 'don't know'

For this question, $45.5 \%$ of the students thought that the newly divided cells will share half of the chromosomes of the original cell though only $33 \%$ of them could give a proper reason for their answer[e.g. "During meiosis the chromosome number reduces to half"; "Due to meiotic cell division. One student thought that the new cell will have only two chromosome since, "The egg cell contain 1 sperm and 1 egg cell (i.e. half the original number)" showing confusion between the germ cell and chromosome as well as the process as a whole.

With reasons like, "Cell division is constructive, hence chromosome number increases with frequent division"; "same with mitosis, because they are of the same species", $28 \%$ of the students thought that the number will be twice and $14.5 \%$ of the students said that the number will remain same who could not make any distinction between mitosis and meiosis. Twelve per cent of the students did not answer.

Question 2. Would the new egg cell and the original cell contain the same or different genetic information?

Same different don't know

Please tick ONE, then give reasons for your answer.

Table 2. Students' responses about meiosis

\begin{tabular}{|c|c|c|c|c|}
\hline Questions & \multicolumn{4}{|c|}{ Responses of students $(\mathrm{N}=289)$} \\
\hline $\begin{array}{l}1 \text { Number of chromosomes } \\
\text { in a cell }(2 n=4) \text { after meiosis }\end{array}$ & $\begin{array}{c}8 \\
28 \% \\
\end{array}$ & $\begin{array}{c}4 * \\
14.5 \% \\
\end{array}$ & $\begin{array}{c}2 \\
44.5 \% \\
\end{array}$ & $\begin{array}{c}\mathrm{DN} \\
12 \% \\
\end{array}$ \\
\hline $\begin{array}{c}2 \text { Genetic information before } \\
\text { and after meiosis }\end{array}$ & $\begin{array}{l}\text { same* } \\
56.5 \% \\
\end{array}$ & $\begin{array}{c}\text { different } \\
36.5 \% \\
\end{array}$ & \multicolumn{2}{|c|}{$\begin{array}{l}\mathrm{DN} \\
7 \% \\
\end{array}$} \\
\hline $\begin{array}{l}3 \text { Type of cell division in } \\
\text { different tissues }\end{array}$ & $\begin{array}{l}\text { muscle } \\
\text { testis } \\
\text { ovary } \\
\text { kidney } \\
\text { stomach }\end{array}$ & $\begin{array}{c}\text { Yes* } \\
81 \% \\
\text { Yes } \\
39 \% \\
\text { Yes } \\
51.5 \% \\
\text { Yes* } \\
62.5 \% \\
\text { Yes* } \\
58.5 \% \\
\end{array}$ & & $\begin{array}{l}0 \\
\% \\
\% \\
\% \\
\% \\
\% \\
5 \% \\
0 \\
5 \% \\
0 \\
5 \% \\
\end{array}$ \\
\hline 4 Meiosis in plant cells & \multicolumn{2}{|c|}{$\begin{array}{l}\text { Yes* } \\
60 \%\end{array}$} & \multicolumn{2}{|c|}{$\begin{array}{l}\text { No } \\
40 \%\end{array}$} \\
\hline
\end{tabular}

When asked about the choice, $56.5 \%$ of the students thought that the genetic information will remain same while $36.5 \%$ of the students correctly said that the genetic information will be different. Only $10 \%$ gave reasons for their choice saying "Due to meiosis". None of the students used terms like 'crossing over', 'recombination' or 'random distribution of chromosomes'. The incorrect reasons for the correct choice included "Because in plant cell, there are no eggs or sperms", or "It would contain a little bit different 
genetic information since the new cell must obtain some characteristics different from the original one", (close to correct but not mentioning the reason for the variation) or "The zygote formed will have chromosomes from both the parent cells" (confusion between meiosis and reproduction). Students who thought the new cell will have the same genetic information with the original cell during meiosis gave the same reasons as to mitosis. The recombination of DNA particularly in meiosis- I resulting into new genetic information which leads to variation to play an important role in the evolutionary process was overlooked by these students. Seven per cent of the students said they did not know the answer.

Question 3. For each part of the body listed below please tick ONE to show whether or not you think the cells in that part of the body would divide in this way.

The body parts are:

$\begin{array}{lll}\text { muscle } & \text { yes } & \text { no } \\ \text { testis } & \text { yes } & \text { no } \\ \text { ovary } & \text { yes } & \text { no } \\ \text { kidney } & \text { yes } & \text { no } \\ \text { stomach } & \text { yes } & \text { no } \\ \text { skin } & \text { yes } & \text { no }\end{array}$

(Reason was not asked for this question)

Among the two types of tissues with somatic and germ cells, 50 to $69 \%$ of the students said that somatic cells (muscle, kidney, stomach and skin) do not undergo the same type of cell division (Figure 1) while 72 to $74.5 \%$ of the students thought that testis and ovary undergo similar type of cell division.

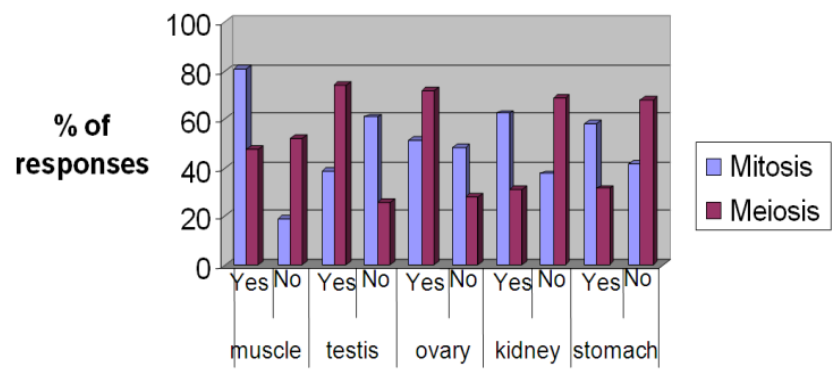

Figure 1. Comparison of students' responses on types of cell division in different tissues

Question 4. So far, the questions in Part 2 have all been about animal cells.

Do you think that this type of cell division, for production of sex cells also occurs in plants?

\section{Yes No Reasons}

Seventy one per cent of the students said that plants also undergo meiotic type of cell division to produce sex cells. Fifty five per cent of them gave a valid reason for their response. These included "Plants also contain sex cells", or "There are some plants which reproduce by sexual reproduction". Reasons for the incorrect response included "Most plants reproduce asexually", or "Because in plant cell, there are no eggs or sperms", or "Plant cell division (sexual) takes place by mitosis", as well as "Since plant system and animal systems are different".

\section{Some Important Observations}

i. In the mitosis section, though majority of the students (44.5\%) thought that the number of chromosome would be double, most of the students $(76.0 \%)$ said the genetic information would remain same. This shows inconsistent representation of their idea about the chromosome and genetic information.

ii. When different tissues (somatic and germ) were given to select whether mitosis takes place in them, $39 \%$ said 'yes' for testis and 51\% said 'yes' for ovary. In somatic tissues the range varied from $58.5 \%$ to $81 \%$ indicated that students did not differentiate between mitosis and meiosis simply based on their location in somatic and reproductive tissues.

iii. When the responses of the students to the 'question 3' of both the 'Part 1' and 'Part 2' were compared, a certain amount of uncertainty became evident (Figure 1). In the same sample, while $81 \%$ of the students thought mitosis takes place in muscle tissue, $48 \%$ again said 'yes' for the same question in the meiosis section. The same pattern is also noticed in answering tissues like testis and ovary. This observation suggests that students were not sure about the occurrence of these two types of cell division in individual tissues.

\section{Discussion}

The goal of science teaching, as a result of last $30 \mathrm{yrs}$ science education reform movement has shifted from simply creating a knowledge base scientific facts to students developing deeper understanding of major concepts within a scientific discipline[10]. Concept of genetics is related to good foundations of other topics like cells (structure and function), cell division, fertilization etc. Cell division (particularly the chromosome movement in the prophase I of meiosis) is difficult to teach by secondary school teachers[5,11-13]. Previous study[1] using the same questionnaire among secondary school students revealed the following observations:

i. The understanding of cell division was "limited, confused and inconsistent."

ii. Though part of cell division process was understood by different students, they had no "coherent conceptual frame work."

iii. Although some awareness of the significance of mitosis and meiosis was present, the students did not seem to have the idea, how these are 'achieved'.

iv. Students were not clear about the nature of difference between mitosis and meiosis. They were also seemed to be confused by the closely similar words, like 'mitosis' and 'meiosis'.

v. Meiosis appeared to be linked with reproduction and confused with 'fertilization'.

vi. Students were also confused by the contradictory words like 'replicating, dividing copying, splitting, multiplying, sharing'.

vii. Many students have little awareness of the relationship 
between chromosomes and genetic information.

The present study with higher secondary students reflected similar types of confusions and difficulties in understanding the cell division processes as noted by Lewis and her group among middle school students. Therefore, it can be presumed that misconceptions among the higher secondary students have been carried from their school level.

\section{Conclusions}

In further study it was noticed that similar misconceptions even exists among undergraduate (B. Sc) biology major students (data not presented). Thus, the problem in understanding cell division processes persists not only at school level but also at higher levels. Since many of these students will be the future teachers, it is possible that their misconceptions in cell division will pass to future generations of students. The observation also corroborates the concern raised in the earlier study that students' understanding in the transmission of genetic information is guided by their understanding of cell division processes[4].

\section{Implications for Teaching Genetics}

Banet and Ayuso[14] suggested that understanding of the relation between inheritance and cell structure and function is important for the students. Bahar et al.[15] also viewed that the problem in understanding monohybrid and dihybrid crosses and linkage is rooted in the difficulty of understanding between mitosis and meiosis. He assumes this may be due to the teaching of these two topics side by side. Lewis et al.[1] found though majority of the students seemed to be aware that there was some difference between mitosis and meiosis, they were unclear about the nature of difference. Some of the students recognized only mitosis as cell division and confused meiosis with fertilization. Lewis and WoodRobinson[9] found that the students have difficulty with the contradictory terms like- divide, replicate, copy, share, split, reproduce and multiply. They also found that students had little awareness of the relationship between chromosomes and genetic information.

Oztap et al.[5] pointed out that subjects, closely related, such as cell division, DNA-chromosome relationship were not taught well by the teachers in higher education, which reflected in the confusion and misunderstanding of the students. They suggested a review of teaching methodology at least at higher education to equip the teaching community for teaching these particular subjects.

According to Brown[16], teaching of cell division, particularly the movements of the chromosomes and the various events which accompany them needs additional teaching aids like, photographs, film and video, time-lapse phase contrast microscopy, models etc. to explain the dynamic nature of the process. However considering the Indian school education scenario (or even the college level educa- tion for the same) it is not easy to adopt such measures due to financial constrains. In a recent article, Skirton et. al[17] expressed the need of a common minimum competence in genetics among health professionals in Europe in view of the emergence of the possible use of generic drugs. An expert group working under the Euro Gentest project and European Society of Human Genetics Education Committee opined that a practical solution to the need to establish common standards for education and practice in genetic health care. Stavroulakis[18] discussed an alternative method for presenting the topics of meiosis to students. Using socks, yarns, clips, pins, foam boards, it was demonstrated, how such easily available cost effective materials may be used to explain topics like homologue behaviour during meiosis, chromosomal replication, mutation and rearrangement, amniocentesis and the human karyotype or even RNA-splicing. Moreover, by doing these experiments themselves, students can feel confident about their level of understanding of these topics. Use of different colored electric-wires in the class room can help to visualize the 'crossing over' and 'chiasma formation' in three dimensional structure and understand these phenomena with much better clarity which is not possible only through diagrams. A number of web sites, like www.genome.gov/10005911, www.encyclopedia.com/video are available, which contains animations and real-time videos on mitosis and meiosis. We should explore these seemingly infinite laboratory pedagogical techniques for teaching topics like cell division to improve the level of understanding among students from school levels so that they can apply their understanding to other related topics in genetics.

\section{ACKNOWLEDGEMENTS}

My sincere thanks to Dr. J. Lewis and Prof. K. Fisher for providing the papers and workbooks related to this work as well as giving suggestions and advice while doing this work. The Principals of the three colleges (St. Edmund's College, St. Mary's College and Shillong College of Meghalaya, India) where the tests were done and the teachers involved in conducting the tests are also gratefully acknowledged.

\section{REFERENCES}

[1] Lewis J., Leach, J. and Wood-Robinson C. (2000a) Chromosomes: the missing link-young people understand of mitosis, meiosis, and fertilization. Journal of Biology Education 34(4): 189 - 199.

[2] Lewis J., Leach J. and Wood-Robinson C. (2000b) All in the genes? - Young people's understanding of the nature of genes. Journal of Biology Education 34(2): 74 - 79.

[3] Lewis J., Leach J. and Wood-Robinson C. (2000c) What's in a cell? - Young people's understanding of the genetic relationship between cells, within an individual. Journal of Bi- 
ology Education 34(3): 129 - 132.

[4] Chattopadhyay A. (2005) Understanding of genetic information in higher secondary students in northeast India and the implications for genetics education. Cell Biology Education 4(Spring): 97-104.

[5] Oztap H., Ozay E. and Oztap F. (2003) Teaching cell division to secondary school students: an investigation of difficulties experienced by Turkish teachers. Journal of Biology Education 38(1):13-15.

[6] Maier S. (2004) Misconception Research and Piagetian Models of Intelligence. Oklahama Higher Education Teaching and Learning Conference.

[7] Pathare S., Pradhan, H. C. (2004) Students' alternative conceptions in Pressure, Heat and Temperature. Abstract in episteme 1 International Conference to Review Research on Science, Technology and Mathematics Education in Goa, December 13-17, 2004, 38-41.

[8] Mahajan B. S., Chunawala S. (1999) Indian secondary students' understanding of different aspects of health. International Journal of Science Education 21(11): 1155-1168.

[9] Lewis J., Wood-Robinson C. (2000) Genes, chromosomes, cell division and inheritance-- do students see any relationship? International Journal of Science Education 22(2): 177 195.

[10] Tanner K., Allen D. (2005) Approaches to biology teaching and learning: understanding the wrong answers- teaching toward conceptual change. Cell Biology Education 4(Summer): 112-117.
[11] Cho H. H., Kahle, J. B. and Nordland, F. H. (1985) An investigation of high school biology textbooks as sources of genetics and some suggestions for teaching genetics. Science Education 69: 707-719.

[12] Kindfield A. C. H. (1994) Understanding a basic biological process: Expert and novice models of meiosis. Science Education 78: 255-283.

[13] Yip D. Y. (1998) Identification of misconceptions in naive biology teachers and remedial strategies for improving biology learning. International Journal of Science Education 20: 461-477.

[14] Banet E., Ayuso G. E. (2003) Teaching of biological inheritance and evolution of living beings in secondary school. International Journal of Science Education 25(3): 373 - 407.

[15] Bahar M., Johnstone A. H. and Hansell M. H. (1999) Revisiting learning difficulties in biology. Journal of Biology Education 33: 84-86.

[16] Brown C. R. (1995) The Effective Teaching of Biology. Longman publishing, New York, USA.

[17] Skirton H., Lewis C., Kent A. and Coviello D. A, the members of Eurogentest Unit 6 and ESHG Education Committee (2010) Genetic education and the challenge of genomic medicine: development of core competences to support preparation of health professionals in Europe. European Journal of Human Genetics 18, 972-977.

[18] Stavroulakis A. M. (2005) Meio-socks and Other Genetic Yarns. The American Biology Teacher 67(4): 233-238. 